\title{
Development of Dry Mixtures for Protein- Carbohydrate Drinks Used for Sports Nutrition
}

\section{Tatyana Anatolyevna Ershova*, Svetlana Dmitrievna Bozhko, Anna Nikolaevna Chernyshova, Julia Anatolyevna Gavrilova}

Far Eastern Federal University, Vladivostok, Russia

\begin{abstract}
This work is aimed at developing mixtures of protein-carbohydrate drinks used in sports nutrition. Specialized protein-carbohydrate products are the powdered food mixtures with a high content of proteins and carbohydrates required for maintaining and increasing the muscle mass, restoring the glycogen levels in the muscles and the liver, and for correcting the diet of an athlete. At the first stage, theoretical work was carried out aimed at the generalization and analysis of scientific literature. Based on the literature review, biomedical and technological requirements for specialized protein-carbohydrate products for the nutrition of athletes were systematized. In accordance with the requirements, the components (Fonterra WPC 80 protein, skim milk, fructose, cocoa powder, egg albumin, maltodextrin, thickener, natural dyes, flavoring substances) were selected and justified, and the formulation of the developed products was calculated. Further research was aimed at studying the influence of product components and technological factors on the physicochemical properties of carbohydrates and proteins in the model "protein-polysaccharide-water" system. Calculation of the biological value of protein preparations was conducted, as well as the experimental studies of the dry mixing technology aimed at selecting the sequence of the introduction of components for the production of dry multi-component specialized products. Based on theoretical studies and generalizations, technological requirements and modes have been specified, and the technology of dry mixtures of protein-carbohydrate drinks for sports nutrition has been developed. Product optimization, its physicochemical, and organoleptic studies have allowed developing draft technical documentation for dry mixtures of protein-carbohydrate drinks for sports nutrition.
\end{abstract}

Keywords: Protein-carbohydrate mixtures, maltodextrin, egg albumin, whey protein, drink concentrates

\section{Introduction}

Currently, making specialized products for sports nutrition is an urgent task for the modern food industry [1-5]. The popularity of this group of food products in Europe, the USA, and Russia is shown by the statistics of the qualitative and quantitative changes in the food market. Highly skilled athletes often experience deficiency of the key macro- and microcomponents, which significantly impairs the athletic performance and the overall health, therefore, one of the solutions to this problem is including specialized protein-carbohydrate products with high biological value into the diet of athletes so that they can quickly restore the glycogen reserves in the muscles and the liver, respectively, and prevent the loss of muscle protein during intensive workouts.

The range of specialized protein-carbohydrate products for sports nutrition is widely presented in the market by domestic and, for the most part, foreign manufacturers. In recent years rapid advances have been seen in the development and use of specialized protein-carbohydrate food products for athletes. However, industrial production in our country is very limited [1, 6-10]. Currently, the best sources of high-quality protein are milk proteins. Milk proteins consist of casein $(85 \%)$ and whey proteins (15\%). They are digested and absorbed evenly: first, low- molecular whey proteins, followed by high-molecular casein. This property of milk protein is especially important when it is used for dietary purposes and muscle recovery after workouts of various intensities $[11,12]$. To better provide amino acids to the organism before, during, and after exercises, specialized proteincarbohydrate products for athletes should contain concentrates, isolates, and hydrolysates of whey protein. To further stimulate the synthesis of muscle fibers in the organism, various micronutrients, especially vitamins, minerals, etc. are usually added to specialized protein-carbohydrate food products. As a rule, they include well-chosen combinations of vitamins, mineral premixes, and other nutrients in certain ratios, rather than individual vitamins and minerals. This is because many chemical processes in the organism are catalyzed simultaneously by several interacting vitamins, macro- and microelements [13-17]. The carbohydrate complex in specialized protein-carbohydrate food mixtures for the nutrition of athletes is represented by several types of carbohydrates - maltodextrin, glucose polymers, and fructose [3, 14, 18-25].

*Corresponding author: Tatyana Anatolyevna Ershova, Far Eastern Federal University, Vladivostok, Russia. E-mail: ershova_t.a@mail.ru 


\section{Literature review}

Specialized protein-carbohydrate products are powdered food mixtures with a high content of proteins and carbohydrates required for maintaining and increasing the muscle mass, restoring the glycogen levels in the muscles and the liver, and for correcting the diet of an athlete [26-28]. Most often, specialized protein-carbohydrate-enriched food products for athletes are available in the form of powders and are used as drinks. The content of glycogen in the muscles during intensive exercises may be reduced in less than an hour, but restoring it to the previous level using everyday diet takes several days [29]. The restoration of the glycogen levels and enhancing the synthesis of new muscle fibers are supported by additional intake of carbohydrates and proteins into the organism of an athlete, which is often achieved by including specialized protein-carbohydrate food mixtures with high biological value into the diet of the athletes [1, 20,30].

In developing this type of product, environmentally friendly raw materials of animal and plant origin must be used along with biologically active supplements that improve their functional and consumer qualities [31-36]. The technology of manufacturing specialized protein-carbohydrate products for sports nutrition should envisage highly efficient manufacturing processes that preserve the nutritional value of raw materials and ensure obtaining a product with desired functional properties. In this regard, the most promising is the use of dry mixing technology $[37,38]$. Optimization of the processes for the production of specialized dry products using the method of components dry mixing has several specific features since the issue discussed is biological systems and certain components mixing conditions, which may have a significant effect on their quality. Therefore, successful optimization of the mixing process to develop a product technology requires additional study of this aspect.

\section{Materials and methods \\ 3.1 General description}

During the experimental part, the objects of the study were the components of the developed protein-carbohydrate product, and the Whey protein finished product. Considering their high biological value, whey proteins and egg albumin were used in the product as a source of protein: concentrate of dried egg albumin of the OVOPROT brand (production of OVOPROT INTERNATIONAL, Argentina), the dry concentrate of whey protein of the Fonterra 80 brand (production of Fonterra Ltd, New Zealand), the dry concentrate of whey protein of the Lactomin 80 brand (production of Deutschland $\mathrm{GmbH}$, Germany). The physicochemical properties of the components are presented in Tables 1-3.

Whey proteins and egg albumin have the highest degradation and digestibility rates among whole proteins. The amino acid composition of the considered proteins is the closest to the amino acid composition of human muscle tissue, and in terms of the content of essential amino acids and branched-chain amino acids (BCAAs): valine, leucine and isoleucine, they surpass all other proteins of animal and vegetable origin. BCAAs are the main initiating factors in eliminating energy deficits during their metabolism and create the conditions for the favorable occurrence of energy-dependent synthetic processes, including glycogen formation. Skim milk powder in its composition contains amino acids essential for the body, B vitamins, vitamins A and D, as well as minerals: phosphorus, potassium, calcium, sulfur, magnesium, chlorine, and others. Proteins of milk powder are slowly absorbed, and for a long time, serve as a source of replenishment of the level of amino acids in the blood.

Table 1: Physicochemical properties of protein-containing components

\begin{tabular}{|c|c|c|c|c|c|}
\hline Name of components & $\begin{array}{c}\text { Protein } \\
\text { content, } \% \text { not } \\
\text { less }\end{array}$ & $\begin{array}{l}\text { Fat content, } \% \\
\text { min }\end{array}$ & $\begin{array}{l}\text { Mass fraction of } \\
\text { moisture, } \% \text { max. }\end{array}$ & Ash, $\%$ max. & Solution $\mathrm{pH}$ \\
\hline $\begin{array}{l}\text { Concentrate of egg albumin of } \\
\text { the OVOPROT brand }\end{array}$ & 85.0 & 0.02 & 6.0 & 4.5 & $5.0-7.5$ \\
\hline $\begin{array}{l}\text { Concentrate of whey protein of } \\
\text { the Fonterra } 80 \text { brand }\end{array}$ & 80.0 & 5.0 & 4.5 & 3.0 & $6.1-6.5$ \\
\hline $\begin{array}{l}\text { Concentrate of whey protein of } \\
\text { the Lactomin } 80 \text { brand }\end{array}$ & 80.0 & 3.0 & 5.5 & 4.0 & $6.5-7.2$ \\
\hline $\begin{array}{l}\text { Whey protein concentrate of the } \\
\text { Milkiland } 80 \text { brand }\end{array}$ & 80.0 & 8.0 & 5.5 & 3.5 & $6.1-6.5$ \\
\hline
\end{tabular}

Table 2: Physicochemical properties of the components

\begin{tabular}{lccccc}
\hline \multicolumn{1}{c}{ Name of components } & $\begin{array}{c}\text { Protein content, } \% \\
\text { not less }\end{array}$ & Fat content, \% max & $\begin{array}{c}\text { Carbohydrate } \\
\text { content, } \% \text { max. }\end{array}$ & $\begin{array}{c}\text { Mass fraction of } \\
\text { moisture, } \% \text { max. }\end{array}$ & $\begin{array}{c}\text { Ash, } \% \text { max. } \\
\text { Skim milk powder }\end{array}$ \\
Frima dry vegetable cream & 49.9 & 1.0 & 41.1 & 5.5 & 8.0 \\
& 2.0 & 26.0 & 62.0 & 4.5 & 3.5
\end{tabular}

Table 3: Physicochemical properties of berry powders

\begin{tabular}{lccccr}
\hline Name of components & $\begin{array}{c}\text { Protein content, } \% \\
\text { not less }\end{array}$ & $\begin{array}{c}\text { Fat content, } \% \\
\text { min. }\end{array}$ & $\begin{array}{c}\text { Carbohydrate } \\
\text { content, } \% \text { max. }\end{array}$ & $\begin{array}{c}\text { Sugar content, } \% \\
\text { max. }\end{array}$ & $\begin{array}{c}\text { Mass fraction of } \\
\text { moisture, } \% \text { max. }\end{array}$ \\
\hline Dried Raspberry Powder & 8.2 & 4.0 & 55.1 & 54.0 & $4.0-5.0$ \\
Dried Strawberry Powder & 8.2 & 4.0 & 55.1 & 54.0 & $4.0-5.0$ \\
\hline
\end{tabular}


The use of a mixture of maltodextrin and fructose (a mixture of carbohydrates with high and low glycemic index) leads to an increase in the rate of oxidation of exogenous carbohydrates compared to using each carbohydrate separately [11, 13, 30, 39]. As sources of carbohydrates, GLUSIDEX 19 maltodextrin (production of ROQUETTE, France), DE 18-20, and CornSweet fructose (ADM, USA) in a 1:3 ratio were used. Dry skim milk (production of Lepel Dairy Canning Plant, JSC Vitebsk Meat Plant, Belarus) and dry vegetable cream Frima (production of DONGSUH, Korea) were selected as an additional source of protein. Xanthan gum (production of Deosen Biochemical Ltd, China), with the basic substance content of $80 \%$, was used as a stabilizer for emulsions and suspensions, and also as a thickener increasing the viscosity of beverages. When creating the flavor and aroma range of the product being developed, natural berry powders (strawberry and raspberry) were used that provided high organoleptic properties of the finished product: dried raspberry powder $0-2 \mathrm{~mm}$ (production of YANTAI XUEHAI FOODSTUFFS CO., LTD China), dried strawberry powder 3 - 6 $\mathrm{mm}$ (production of YANTAI XUEHAI FOODSTUFFS CO., LTD China). Luxomix beta-carotene food dye (production of BARGUS TRADE, Russia); Luxomix carmine food dye (production of BARGUS TRADE, Russia); and Vanilla, Chocolate, Strawberry, Raspberry food flavors (production of BARGUS TRADE Russia) were used as dye and flavoring agents. Food flavors met the requirements of TR TS 029/2012 "Safety requirements for food additives, flavors, and technological aids." Based on the experimental studies of the functional properties of the product components, testing the sequence of introducing components for mixing and following the technological requirements for the product, the composition, and flowchart for the production of the dry protein-carbohydrate product named "Whey protein" for athletes nutrition was developed. The technological process of the developed product production was carried out according to the technological scheme. In conformity with the technological scheme, the production of a product in the form of dry powder included the following stages: acceptance and storage of raw materials; preparation of raw materials; dry mixing of components in the mixer; product packaging; packaging and labeling of the finished product.

The production of Whey protein was carried out by dry mixing of the components. Since the final product is a multicomponent mixture, to obtain a high-quality product, it was advisable to carry out the production by sequential mixing according to a three-stage scheme. At the first stage, microcomponents were mixed: skim milk, xanthan gum, dyes, food flavors. Mixed components were sent to a hopper for temporary storage. At the second stage, the mixture prepared at the first stage was mixed with maltodextrin, whey protein preparation, egg white preparation, vegetable cream, and fructose.

In the third stage, the mixture prepared at the second stage was mixed with sublimated berries. Mixing time was 50-60 minutes when rotating in a mixer at $50 \mathrm{rpm}$. After mixing, the finished product was put into a weighing batcher and then the filling machine. Products were packaged in consumer packaging: a jar or bag made of polymeric materials with a measuring spoon or in sachets intended for single use. In choosing the components and in developing the formulations of the mixtures for proteincarbohydrate drinks, the balance of essential amino acids relative to the chosen reference protein of FAO/WHO was taken into consideration [40]. With this aim in mind, the amino acid balance was optimized. Specifically, the content of essential amino acids and their total balance in the studied protein concentrates were quantified. Not less important criteria for choosing protein concentrates used for creating protein-containing mixtures, in addition to their biological value, are their physicochemical characteristics. To determine the particle size distribution, the sieve analysis was used, based on the mechanical separation of the particles into size classes on sieves with holes of various sizes. The material that remained on the sieve after sieving is called BALANCE, and the material that has passed through the sieve is called THROUGHS.

In the work, the method of dispersion assessment in concentrates was used (GOST 1513.3-77). A sample taken from a pooled sample, weighing $40 \mathrm{~g}$ with the accuracy of not more than $0.1 \mathrm{~g}$, was placed in a beaker, then $200 \mathrm{~cm}^{3}$ of water heated to a temperature of $(60 \pm 2)^{\circ} \mathrm{C}$ was added, and the mixture was mixed thoroughly until a fine suspension was obtained and set at rest. The higher the dispersion of the suspension particles was, and the longer they were kept in suspension, the higher the quality of the drink was. The suspension was considered sufficiently dispersed if, in two minutes after mixing, noticeable sludge did not form. The height of the sludge level was determined using the coordinate paper. The solubility index was determined by the method of determining the dry milk products' solubility index according to GOST 30305.4-95. The essence of the method consists in determining the amount of undissolved sediment in the sample of the analyzed preparation. To determine the dispersibility, the method of determining the dissolution rate was used, in which mixing continued until all lumps of the dry concentrate were completely dispersed; and the dispersibility was equal to the mixing duration in seconds until all lumps were dissolved [28]. The wettability of the dry concentrate was determined by the method of Moore. Dry concentrate in the amount of $1.7 \mathrm{~g}$ was poured into a special funnel closed from below with a glass plate. Under the funnel, there was a beaker filled with $25 \mathrm{ml}$ of distilled water with a temperature of $(20 \pm 2)$ ${ }^{\circ} \mathrm{C}$ Then the plate was removed, the dry concentrate was poured into water, and the time of its complete immersion was recorded. Wettability was assessed by the time required to completely wet the dry concentrate. The results of the studies were processed in Microsoft Office Excel 2013. Studies were carried out in three- to five-fold repetition. The research results were processed using the methods of statistical analysis with the determination of the arithmetic mean value and mean square error.

\section{Result analysis}

The most important factors contributing to the enhancement of muscle protein synthesis required for ensuring high training level of the muscle system and its adaptation to power loads include the high biological value of food protein, which reflects the balance of essential amino acids with respect to the selected FAO/ WHO reference protein [40]. To this end, an amino acid balance optimization was carried out, namely, quantitative assessment of the correspondence of the content of essential amino acids and their total balance in the studied protein concentrates. The process of optimization involved such criteria as amino acid score, the ratio of the amino acid composition utility $(\mathrm{U})$, and the coefficient of comparable redundancy of the essential amino acid content $\left(\sigma_{c}\right)$. 


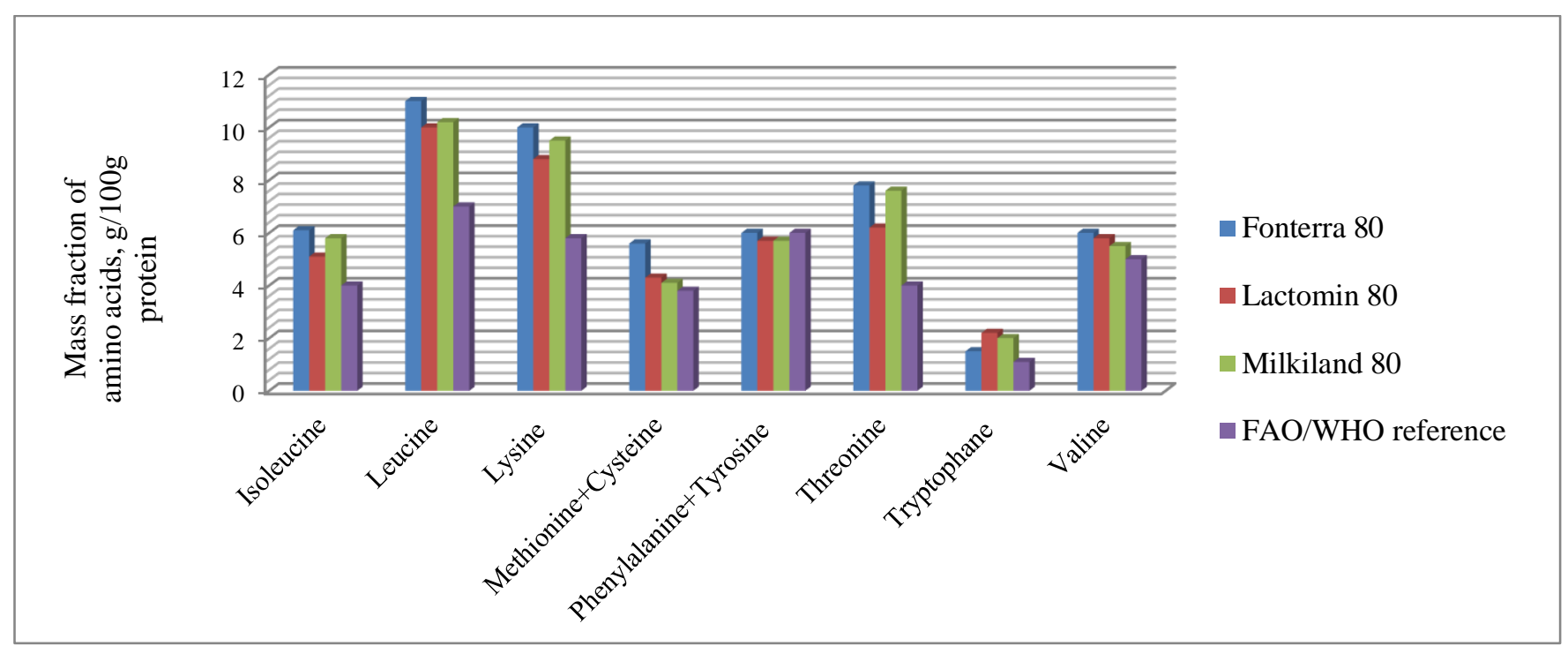

Figure 1: The comparative histogram of the essential amino acids content in the studied whey protein concentrates

To characterize the rationality of using amino acids, proteins were qualitatively assessed by the coefficient of amino acid composition utility $(\mathrm{U})$ and indicator of comparable redundancy $\left(\sigma_{C}\right)$. The content of essential amino acids in the studied protein concentrates is shown in Figure 1. Analysis of the histogram of the amino acid composition shows that the most balanced relative to the reference $\mathrm{FAO} / \mathrm{WHO}$ protein is dry whey protein concentrate of the Fonterra 80 brand. The indicators that characterize its amino acid balance $\left(\mathrm{C}_{\min }, \mathrm{U}, \sigma_{c}\right)$ fully confirm the high biological value of protein. The indicators of the amino acid balance of the whey proteins are shown in Table 4.

Table 4: The indicators of the amino acid balance of dry whey

\begin{tabular}{llll}
\multicolumn{4}{c}{ proteins } \\
\hline Indicator & $\begin{array}{l}\text { Milkiland } \\
80\end{array}$ & $\begin{array}{l}\text { Lactomin } \\
80\end{array}$ & Fonterra 80 \\
\hline $\begin{array}{l}\text { The minimum } \\
\text { score } \mathrm{C}_{\text {min }} \text {, share } \\
\text { units }\end{array}$ & 0.83 & 0.85 & 1.00 \\
$\begin{array}{l}\text { The coefficient of } \\
\text { utility U, share }\end{array}$ & 0.61 & 0.63 & 0.67 \\
$\begin{array}{l}\text { units } \\
\begin{array}{l}\text { The coefficient of } \\
\text { comparable } \\
\text { redundancy } \sigma_{c}, \mathrm{~g}\end{array}\end{array}$ & 22.92 & 21.53 & 18.25 \\
\hline
\end{tabular}

The concentrates of dry whey proteins (Lactomin 80 and Milkiland 80) contain limiting amino acids — phenylalanine and tyrosine, which decrease the biological value of these proteins and reduce the possibility of their utilization by the organism.

The factors that determine the solubility of dry protein concentrate include the physicochemical properties of particles of the product (dispersion, shape, and structure). Since the main components of the developed product are maltodextrin, whey proteins, and egg albumin, the granulometric composition of these components was studied. The particle size distribution and the size depend on the process of obtaining the components and influence bulk density, flowability, and quick dissolution of the finished product. The results of analyzing the distribution of the actual particles in the components of maltodextrin and proteins are evidence of their different granulometric composition. It should be noted that particles of the Fonterra 80 brand whey protein dry concentrate and the OVOPROT brand dried egg concentrate of albumin represent rather large particles. At the same time, most particles in the concentrate of the Milkiland 80 brand dry whey protein are also linked into agglomerates; however, the average size of individual particles in the agglomerates in the Milkiland 80 brand whey protein dry concentrate is less than the size of the particles in the Fonterra 80 brand whey protein dry concentrate. Given the results of analyzing the actual distribution of particles and functional and technological properties (balanced carbohydrate composition and solubility), the most rational source of carbohydrates was determined to be the GLUSIDEX 19 maltodextrin.

The high bulk density of the protein or polysaccharides concentrate may indicate the presence of a sufficiently large number of single particles and minor amounts of agglomerates, which, in turn, affects the product dissolution rate. The results of analyzing the actual particle distribution in the studied components of proteins and polysaccharides are shown in Table 5. It should be noted that the granulometric composition, the shape and the size of particles, the degree of compaction, and their mutual arrangement determine important indicators of dry protein products such as the wettability and the dissolution rate. The change in the rate of protein solubility is shown in Figure 2.

The obtained graphic dependencies show that the maximum dissolution rate of all studied components is observed upon increasing the share of maltodextrin in the composition, but given the functional orientation of the developed product, the best is the protein to carbohydrates ratio of 40:60. This combination of the components provides quick dissolution of the product without affecting its functionality. 
Table 5: The results of analyzing the actual particles distribution in the studied components of proteins and maltodextrin

\begin{tabular}{|c|c|c|c|c|c|c|}
\hline \multirow[b]{2}{*}{ Component names } & \multicolumn{2}{|c|}{ Bulk density indicators, $\mathrm{kg} / \mathrm{m}$} & \multicolumn{4}{|c|}{ Mass fraction of particles (in \%) of the total weight with their size, $\mu \mathrm{m}$} \\
\hline & $\begin{array}{l}\text { The volumetric } \\
\text { bulk density }\end{array}$ & Bulk density & $<5$ & $5-10$ & $10-20$ & $>20$ \\
\hline Fonterra 80 & $238.4 \pm 1.2$ & $367.8 \pm 1.1$ & $15.5 \pm 2.1$ & $26.2 \pm 1.8$ & $47.1 \pm 2.3$ & $6.2 \pm 1.7$ \\
\hline Lactomin 80 & $313.2 \pm 0.9$ & $455.4 \pm 1.4$ & $57.1 \pm 2.7$ & $25.9 \pm 2.0$ & $12.7 \pm 2.7$ & $4.3 \pm 2.4$ \\
\hline Milkiland 80 & $268.5 \pm 1.4$ & $282.3 \pm 1.3$ & $30.2 \pm 3.1$ & $27.7 \pm 2.4$ & $34.5 \pm 1.8$ & $7.6 \pm 2.1$ \\
\hline $\begin{array}{l}\text { OVOPROT egg } \\
\text { albumin }\end{array}$ & $266 \pm 1$ & $390 \pm 1.3$ & $20.7 \pm 1.5$ & $30.3 \pm 2.4$ & $43.5 \pm 1.1$ & $5.5 \pm 2.0$ \\
\hline $\begin{array}{l}\text { GLUSIDEX } 19 \\
\text { Maltodextrin }\end{array}$ & $335 \pm 1.5$ & $359 \pm 1.2$ & $16.5 \pm 2.1$ & $30.2 \pm 1.8$ & $50.1 \pm 2.3$ & $7.2 \pm 1.7$ \\
\hline
\end{tabular}

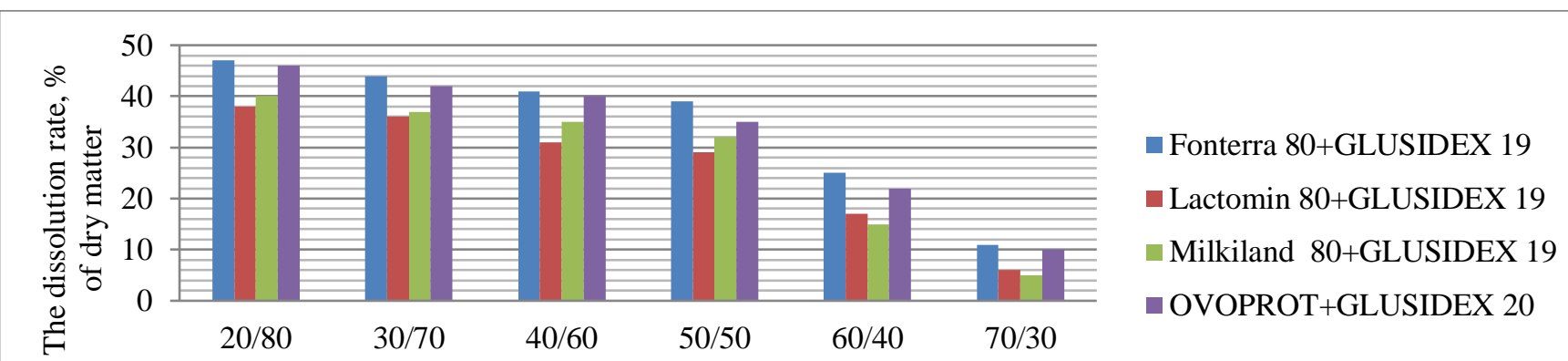

The protein/polysaccharide ratio, $\%$

Figure 2: Change in the speed of proteins solubility depending on their ratio to polysaccharides (Maltodextrin GLUSIDEX 19)

The highest dissolution rate was observed in the Fonterra 80 dry whey protein concentrate and the OVOPROT dried egg albumin concentrate. This can likely explain the quantitative ratio between large and small particles and the presence of agglomerates in the composition of these components. The dissolution rate and the wettability are significantly affected by the temperature of the water in which the product is restored. Figures 3 and 4 show the curves that demonstrate the dynamic changes of wettability and the dissolution rate of the studied components of whey proteins, depending on the water temperature. The obtained graphical dependencies show that the minimum wetting time and the maximum dissolution rate of all studied components are observed in the temperature range between 40 and $50{ }^{\circ} \mathrm{C}$. With the water temperature over $50{ }^{\circ} \mathrm{C}$, the process of wetting and dissolution deteriorates due to the formation of a heavily soluble film on the surface of the product. At the same time, among the studied protein concentrates, the best values of the studied parameters in the entire temperature range were noted in the Fonterra 80 dry whey protein concentrate. This is primarily due to the ratio of fine and coarse particles and the presence of agglomerates in the concentrate. Thus, analyzing the data obtained in studying the physicochemical characteristics and the biological value of the studied protein concentrates, a conclusion can be made that the use of dry concentrate of the Fonterra 80 whey protein will ensure obtaining a product with the desired properties following the technological requirements. According to the results obtained and based on the chemical composition of the ingredients, the formulation of the proteincarbohydrate product named Whey protein was calculated, which is presented in Table 6 .

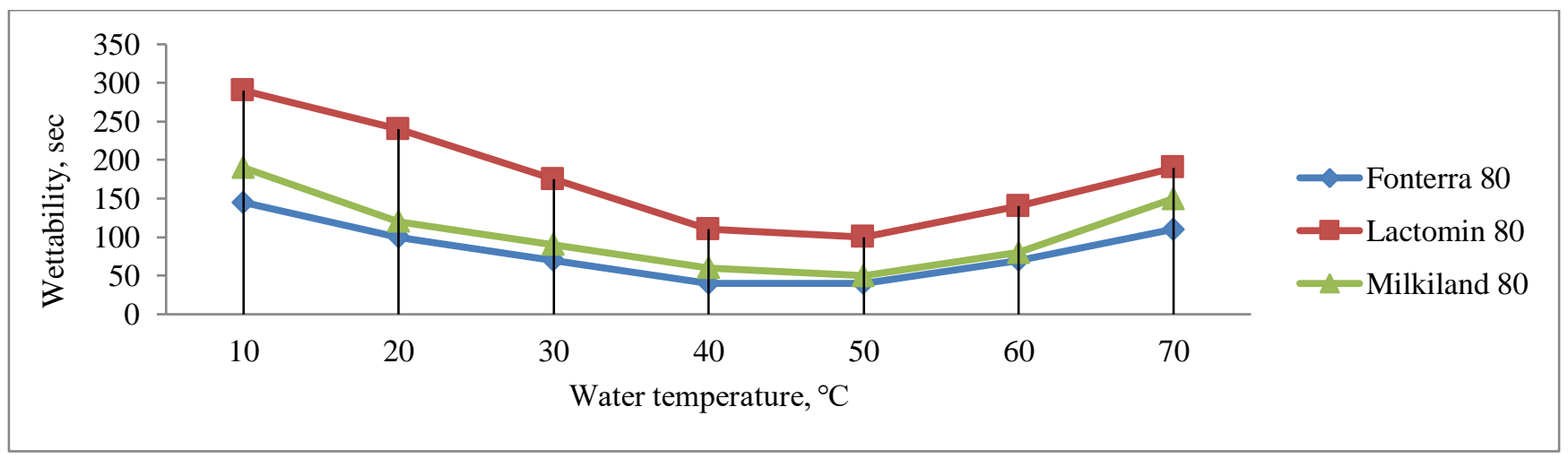

Figure 3: The effect of water temperature on the wettability of the studied concentrates of dry whey proteins 


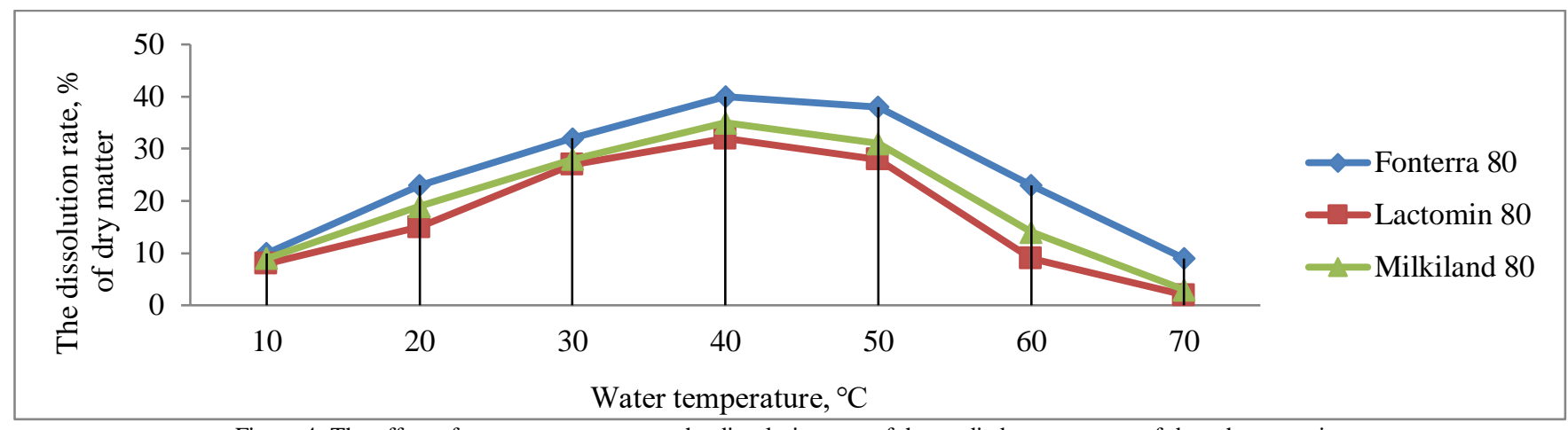

Figure 4: The effect of water temperature on the dissolution rate of the studied concentrates of dry whey proteins

Table 6: Estimated formulation of dry mixtures of protein-carbohydrate drinks named Whey protein

\begin{tabular}{|c|c|c|c|c|}
\hline \multirow{2}{*}{ Raw material name } & \multicolumn{4}{|c|}{ Mass fraction of components, $\%$} \\
\hline & Chocolate & Vanilla & Strawberry & Raspberry \\
\hline Fonterra WPC 80 protein & 30.0 & 30.0 & 30.0 & 30.0 \\
\hline Egg albumin & 11.0 & - & - & - \\
\hline Maltodextrin & 5.0 & 9.0 & 9.0 & 9.0 \\
\hline Skim milk & 20.0 & 20.0 & 20.0 & 20.0 \\
\hline Fructose & 15.0 & 18.0 & 18.0 & 18.0 \\
\hline Vegetable cream & 6.6 & 11.4 & 10.0 & 10.0 \\
\hline Xanthan gum & 0.2 & 0.2 & 0.2 & 0.2 \\
\hline Cocoa powder & 12.0 & - & - & - \\
\hline Carmine & - & - & 0.2 & 0.2 \\
\hline Carotene & - & 0.2 & - & - \\
\hline Chocolate food flavour & 0.2 & - & - & - \\
\hline Vanilla food flavour & - & 0.2 & - & - \\
\hline Strawberry food flavour & - & - & 0.2 & - \\
\hline Raspberry food flavour & - & - & - & 0.2 \\
\hline Strawberry Sublimated Powder & - & - & 1.4 & - \\
\hline Raspberry Sublimated Powder & - & - & - & 1.4 \\
\hline
\end{tabular}

Following the developed formulation and production technology, samples of the specialized protein-carbohydrate product Whey protein have been developed. The nutritional and energy value of the developed product is shown in Table 7. The physicochemical and organoleptic characteristics of the finished product have been studied. The organoleptic characteristics of dry protein-carbohydrate products and ready drinks (cocktails) are shown in Tables 8 and 9. The samples of dry protein-carbohydrate concentrate and ready drinks have high organoleptic value. The main physicochemical characteristics of the product are shown in Table 10. The product is an easily soluble powder with the maximum duration of dissolution (without a stirrer) of $230-250$ sec.

Table 7: Nutritional and energy value of the dry protein and carbohydrate product for athletes, per $100 \mathrm{~g}$ of the product

\begin{tabular}{ll}
\hline Indicator name & Indicator value \\
\hline Calorific value, kcal & 401.5 \\
Mass fraction of moisture, \%, not more than & 5.0 \\
Mass fraction of carbohydrates, g, & 59.8 \\
Mass fraction of protein, $\mathrm{g}$, & 33.18 \\
Mass fraction of fat, $\mathrm{g}$ & 3.23 \\
\hline
\end{tabular}


Table 8: Organoleptic characteristics of dry protein-carbohydrate products

\begin{tabular}{|c|c|c|c|}
\hline \multirow{2}{*}{ Name } & \multicolumn{3}{|c|}{ Dry protein concentrates characteristic } \\
\hline & Appearance & Taste and smell & Color \\
\hline $\begin{array}{l}\text { Whey protein with chocolate } \\
\text { flavor }\end{array}$ & $\begin{array}{c}\text { Powdered. Easily crumbling lumps } \\
\text { are allowed }\end{array}$ & $\begin{array}{l}\text { The smell of chocolate, the taste is sweet } \\
\text { with a hint of chocolate, without foreign } \\
\text { tastes and odors }\end{array}$ & $\begin{array}{l}\text { brown, } \\
\text { homogeneous }\end{array}$ \\
\hline $\begin{array}{l}\text { Whey protein with vanilla } \\
\text { flavor }\end{array}$ & $\begin{array}{c}\text { Powdered. Easily crumbling lumps } \\
\text { are allowed }\end{array}$ & $\begin{array}{l}\text { The smell of vanilla, the taste is sweet } \\
\text { with a hint of vanilla, without foreign } \\
\text { tastes and odors }\end{array}$ & $\begin{array}{l}\text { beige, } \\
\text { homogeneous }\end{array}$ \\
\hline $\begin{array}{l}\text { Whey protein with } \\
\text { strawberry flavor }\end{array}$ & $\begin{array}{c}\text { Powdered. Easily crumbling lumps } \\
\text { are allowed }\end{array}$ & $\begin{array}{l}\text { The smell of strawberries, the taste is } \\
\text { sweet with strawberry flavor, without } \\
\text { foreign tastes and odor }\end{array}$ & $\begin{array}{l}\text { light pink, } \\
\text { homogeneous }\end{array}$ \\
\hline $\begin{array}{l}\text { Whey protein with raspberry } \\
\text { flavor }\end{array}$ & $\begin{array}{c}\text { Powdered. Easily crumbling lumps } \\
\text { are allowed }\end{array}$ & $\begin{array}{l}\text { The smell of raspberry, the taste is sweet } \\
\text { with raspberry flavor, without foreign } \\
\text { tastes and odor }\end{array}$ & $\begin{array}{l}\text { light pink, } \\
\text { homogeneous }\end{array}$ \\
\hline
\end{tabular}

Table 9: The organoleptic indicators of ready protein-carbohydrate drinks

\begin{tabular}{|c|c|c|c|}
\hline \multirow{2}{*}{ Name } & \multicolumn{3}{|c|}{ The characteristic of ready protein concentrates } \\
\hline & Appearance & Taste and smell & Color \\
\hline $\begin{array}{l}\text { Whey protein with chocolate } \\
\text { flavor }\end{array}$ & $\begin{array}{l}\text { Turbid liquid according to the } \\
\text { recipe, without foreign } \\
\text { inclusions. }\end{array}$ & $\begin{array}{l}\text { The taste is distinct, sweet, or sour-sweet with } \\
\text { the aroma of chocolate, according to the } \\
\text { recipe, without foreign tastes and odors. }\end{array}$ & $\begin{array}{l}\text { Brown, } \\
\text { homogeneous }\end{array}$ \\
\hline $\begin{array}{l}\text { Whey protein with vanilla } \\
\text { flavor }\end{array}$ & $\begin{array}{l}\text { Turbid liquid according to the } \\
\text { recipe, without foreign } \\
\text { inclusions. }\end{array}$ & $\begin{array}{l}\text { The taste is distinct, sweet, or sour-sweet with } \\
\text { the aroma of vanilla, according to the recipe, } \\
\text { without foreign tastes and odors. }\end{array}$ & $\begin{array}{l}\text { Pale yellow, } \\
\text { homogeneous }\end{array}$ \\
\hline $\begin{array}{l}\text { Whey protein with strawberry } \\
\text { flavor }\end{array}$ & $\begin{array}{l}\text { Turbid liquid according to the } \\
\text { recipe, with the inclusion of } \\
\text { strawberries }\end{array}$ & $\begin{array}{l}\text { The taste is distinct, sweet, or sour-sweet with } \\
\text { the aroma of strawberries, according to the } \\
\text { recipe. Without foreign tastes and odors. }\end{array}$ & $\begin{array}{l}\text { Light pink, } \\
\text { homogeneous }\end{array}$ \\
\hline $\begin{array}{l}\text { Whey protein with raspberry } \\
\text { flavor }\end{array}$ & $\begin{array}{l}\text { Turbid liquid according to the } \\
\text { recipe, with the inclusion of } \\
\text { raspberries }\end{array}$ & $\begin{array}{l}\text { The taste is distinct, sweet, or sour-sweet with } \\
\text { the aroma of raspberries, according to the } \\
\text { recipe. Without foreign tastes and odors. }\end{array}$ & $\begin{array}{l}\text { Light pink, } \\
\text { homogeneous }\end{array}$ \\
\hline \multicolumn{4}{|c|}{ Table 10: The main physicochemical characteristics of the developed product } \\
\hline \multicolumn{2}{|r|}{ Indicator } & \multicolumn{2}{|c|}{ Analysis result } \\
\hline \multicolumn{2}{|l|}{ Mass fraction of moisture, $\%$} & \multicolumn{2}{|c|}{$5.32 \pm 0.2$} \\
\hline \multicolumn{2}{|l|}{ Mass fraction of protein, $\%$} & \multicolumn{2}{|c|}{$33.18 \pm 0.1$} \\
\hline \multicolumn{2}{|l|}{ Mass fraction of fat, $\%$} & \multicolumn{2}{|c|}{$3.23 \pm 0.19$} \\
\hline \multicolumn{2}{|l|}{ Mass fraction of ash, $\%$} & \multicolumn{2}{|c|}{$4.82 \pm 0.13$} \\
\hline \multicolumn{2}{|l|}{ Mass fraction of carbohydrates, $\%$} & \multicolumn{2}{|c|}{$59.8 \pm 0.13$} \\
\hline \multicolumn{2}{|c|}{ Solubility index, $\mathrm{cm}^{3}$ of the wet residue } & 0.5 & \\
\hline
\end{tabular}

\section{Conclusion}

The nutrition problem is essential for athletes. The special physiological conditions that power and speed-power athlete experiences, lead to the increasing demands for nutrients, in particular, carbohydrates with different chain lengths, easily digestible proteins and basic micronutrients. However, daily nutrition does not ensure the intake of a sufficient amount of proteins and carbohydrates, and also does not guarantee their necessary ratio. One of the ways to solve this problem is the inclusion in the diet of athletes of specialized proteincarbohydrate products with the high biological value being able to quickly restore glycogen stores in the muscles and liver and prevent muscle protein loss during intense training. In recent years, in the field of development and application of specialized protein-carbohydrate food products for athletes, rapid progress has been outlined; however, industrial production in Russia is very limited, and the technology itself requires objective scientific justification of the principles of their creation. In connection with the foregoing, the development and practical implementation of the technology of dry mixtures of protein-carbohydrate drinks for sports nutrition is relevant.

The composition of dry mixtures of protein-carbohydrate drinks is substantiated based on indicators of nutritional and biological value, as well as the functional orientation of the ingredients. The dissolution rate and viscosity of Whey and egg proteins were determined depending on the polysaccharide content in the model "protein-polysaccharide-water" system. The efficient ratio of 1:2 of the protein to the carbohydrate component 
was determined, at which the reduced product in a given ratio provided its functional properties. Changes in the basic physicochemical parameters of the finished product, based on a change in the particle size distribution and bulk density of the product during dry mixing, were investigated. The influence of technological production modes on product quality indicators was studied. The nutritional value of dry mixtures of proteincarbohydrate drinks for sports nutrition was determined.

The technological requirements for the developed product were selected and systematized. The mass fraction of carbohydrates in the product was $59.8 \%$; the carbohydrate component of the product includes mono- and polysaccharides in a ratio of 1:5; the mass fraction of proteins in the product was $33.2 \%$; essential amino acids score in the protein complex is equal to or higher than one. The form of production of the product was a dry powder, which ensures the long-term preservation of the nutritional value and makes it possible to vary the calorie content and the number of incoming nutrients when consumed in the form of a drink.

In terms of safety (the content of toxic substances, pesticides, antibiotics, radionuclides), as well as microbiological indicators, the product meets the requirements for food products and the requirements of the Technical Regulations of the Customs Union "On the safety of food products", (TR TS 021/2011). According to the requirements, a daily serving of this product provides from 40 to $60 \%$ of the athlete's daily demand for complete protein and carbohydrates. Developed dry specialized protein-carbohydrate mixtures are suppliers of carbohydrates and proteins and also contain various flavoring substances.

\section{Ethical issue}

Authors are aware of, and comply with, best practice in publication ethics specifically with regard to authorship (avoidance of guest authorship), dual submission, manipulation of figures, competing interests and compliance with policies on research ethics. Authors adhere to publication requirements that submitted work is original and has not been published elsewhere in any language.

\section{Competing interests}

The authors declare that there is no conflict of interest that would prejudice the impartiality of this scientific work.

\section{Authors' contribution}

All authors of this study have a complete contribution for data collection, data analyses and manuscript writing.

\section{References}

1. Blom PCS, Hostmark AT, Vaage O, Kardel KR. Effect of different post-exercise sugar diets on the rate of muscle glycogen synthesis. Medicine and Science in Sports and Exercise. 1987; 19:491-496.

2. Latkov NYu, Vekovtsev AA, Koschelev YuA, Bakaytis VI. Relevant problems of sports nutrition. Food and Raw Materials. 2015; 3(1):7785.

3. Arenas-Jal M, Suñé-Negre JM, Pérez-Lozano P, García-Montoya E. Trends in the food and sports nutrition industry: A review. Critical Reviews in Food Science and Nutrition. 2019; 27:1-17. Available from: https://doi.org/doi:10.1080/10408398.2019.1643287

4. Maughan RJ. Carbohydrate-electrolyte solutions during prolonged exercise. In: Lamb DR, Williams MH, editors. Perspectives in Exercise Science and Sports Science. Vol. 4. Ergogenics: The
Enhancement of Sport Performance. Carmel, CA: Benchmark Press; 1991. p. 35-85

5. Zoorob R, Parrish ME, O'Hara H, Kalliny M. Sports Nutrition Needs: Before, During, and After Exercise. Primary Care: Clinics in Office Practice. 2013; 40(2):475-486. Available from: https://doi.org/10.1016/j.pop.2013.02.013

6. Balykova LA, Ivansky SA, Piksajkina OA, Efimova YuA. Rationale for the use of L-Carnitine in sports medicine. Sports medicine: science and practice. 2011; 1:22-29.

7. Bonfanti N, Jimenez-Saiz SL. Nutritional Recommendations for Sport Team Athletes. Sports Nutrition and Therapy. 2016; 1(1):1-2. Available from: http://doi.org/10.4172/2473-6449.1000e102

8. Broughton D, Fairchild RM, Morgan MZ. A survey of sports drinks consumption amongst adolescents. British Dental Journal. 2016; 202(12):639-643. Available from: https://doi.org/10.1038/sj.bdj.2016.449

9. Khanferyan RA, Radzhabkadiev RM, Evstratova VS, Galstyan A, Khurshudyan SA, Semin VB, et al. Consumption of carbohydratecontaining beverages and their contribution to the total calorie content of the diet. Problems of Nutrition. 2018; 87(2):39-43 (in Russian). https://doi.org/10.24411/0042-8833-2018-10017

10. Jacob R, Lamarche B, Provencher V, Laramée C, Valois P, Goulet C, Drapeau D. Evaluation of a Theory-Based Intervention Aimed at Improving Coaches' Recommendations on Sports Nutrition to Their Athletes. Journal of the Academy of Nutrition and Dietetics. 2016 ; 116(8):1308-1315. Available from: https://doi.org/10.1016/j.jand.2016.04.005

11. Artemova EK, Savko ID, Shahgeldyan FG. O metabolicheskoi reaktsii organizma na fizicheskie nagruzki razlichnogo kharaktera [About metabolic reactions of the organism to the physical loads of various nature]. In: Physiology of muscular activity. Papers presented at the International Conference "Physiology of Muscular Activity", held at Moscow, November 21-24, 2000. Moscow, Russia: Fizkul'tura, obrazovanie i nauka; 2000. p. 20-21.

12. Voronoy A, Manko P, Yakovleva E. Obzor rynka sportivnogo pitaniya goroda Sankt Peterburga [Overview of the sports nutrition market in St. Petersburg]; 2003. Available from: https://www.marketing.spb.ru/mr/food/sport_02.htm

13. Davletova NH, Ivanov AV, Tafeeva TA. Analiz ratsionalnosti pitevogo rezhima studentov-sportsmenov razlichnykh spetsializatsii Analysis of the rationality of the drinking conditions of sports students of various specializations]. Hygiene and sanitation. 2016; 95(10):988-991.

14. Ershova TA, Bozhko SD, Chernyshova AN. Razrabotka sukhikh smesei napitkov dlya sportsmenov $\mathrm{v}$ period sorevnovanii Development of dry mixtures for drinks for athletes during competition]. Food industry. 2018; 2:64-68.

15. Lavrinenko SV, Vybornaya KV, Kobelkova IV. Ispolzovanie spetsializirovannykh produktov dlya pitaniya sportsmenov $\mathrm{V}$ podgotovitelnom periode sportivnogo tsikla [The use of specialized products for sportsmen nutrition during the preparatory period of the sports cycle]. Problems of nutrition. 2017; 86(4):99-103.

16. Lygina NI, Rudakova OV, Soboleva YP. Ekonomicheskie faktory razvitiya rynka funktsionalnykh pishchevykh produktov [The economic factors of the market of functional food products development]. Socioeconomic phenomena and processes. 2014; 9(11):115-121.

17. Yukendrup A. Rol uglevodov vo vremya dvigatelnoi aktivnosti (rezultaty issledovanii, voploshchennye $\mathrm{v}$ prakticheskikh rekomendatsiyakh) [The role of carbohydrates during physical activity (the results of studies in practical recommendations)]. Science in Olympic sports. 2014; 1:31-36.

18. Close GL, Hamilton DL, Philp A, Burke LM, Morton JP. New Strategies in Sport Nutrition to Increase Exercise Performance. Free Radical Biology and Medicine. 2016; 98:144-158. Available from: https://doi.org/10.1016/j.freeradbiomed.2016.01.016 
19. Cordrey K, Keim SA, Milanaik R, Adesman A. Adolescent Consumption of Sports Drinks. Pediatrics. 2018; 141(6):1-8. Available from: https://doi.org/10.1542/peds.2017-2784

20. Coyle EF. Timing and method of increased carbohydrate uptake to copy with heavy training, competition and recovery. Journal of Sports Science. 1991; 9(S):29-52.

21. Diel F, Khanferyanb RA. Sports and energy drinks. Foods and Raw Materials. 2018; 6(2):379-391. Available from: http://doi.org/10.21603/2308-4057-2018-2-379-391

22. Granato D, Sávio Nunes D, Barba FJ. An integrated strategy between food chemistry, biology, nutrition, pharmacology, and statistics in the development of functional foods: A proposal. Trends in Food Science and Technology. 2017; 62:13-22. Available from: https://doi.org/10.1016/j.tifs.2016.12.010

23. Uluko H, Liu L, Lv J-P, Zhang Sh. Functional Characteristics of Milk Protein Concentrates and Their Modification. Critical Reviews in Food Science and Nutrition. 2016; 56(7):1193-1208.

24. Khanferyan RA. Specialized sports and tonic drinks: pharmacology of the main components, safety. Sports medicine: science and practice. 2016; 6(4):61-66 (in Russian).

25. Shi X, Summers RW, Schedl HP, Flanagan ShW, Chang R-T, Gisolfi CV. Effect of carbohydrate type and concentration and solution osmolality on water absorption. Medicine and Science in Sports and Exercise. 1995; 27:1607-1615.

26. Millard-Stafford M, Warren GL, Thomas LM, Doyle JA, Snow T. Recovery from run training: Efficacy of carbohydrateprotein beverage. International Journal of Sport Nutrition and Exercise Metabolism. 2005; 15:610-624.

27. Novokshanova AL, Ozhiganova EB. Sportivnye napitki: regidratatsiya organizma kak zhiznenno vazhnyi aspekt [Sports drinks: rehydration of the organism as a vital aspect]. Problems of nutrition. 2013; 6:67-70.

28. RBC. Market study. Analiz rynka funktsionalnykh napitkov v Rossii v 2008 - 2012 gg., prognoz na 2013 - 2017 gg. Analysis of the market of functional drinks in Russia in 2008 - 2012, forecast for 2013 - 2017]; 02.09.2013. Available from: https://marketing.rbc.ru/research/28090/

29. Van Loon LJ, Saris WH, Kruijshoop M. Maximizing postexercise muscle glycogen synthesis: carbohydrate supplementation and the application of amino acid or protein hydrolysate mixtures. AmJ.CIin.Nutr. 2000; 72:106-111.

30. Betts JA, Stevenson E, Williams C, Sheppard C, Grey E. Recovery of endurance racing capacity: effect of carbohydrateprotein mixtures. International Journal of Sport Nutrition and Exercise Metabolism. 2005; 15:590-609.

31. Avstrievskyh AN, Vekovcev AA, Poznyakovskiy VM. Produkty zdorovogo pitaniya: novye technologii, obespechenye kachestva, effectivnost' primeneniya [Products of healthy nutrition: new technologies, quality assurance, application efficiency]. Novosibirsk, Russia: Sib. Univ. Publ.; 2005. 416 p.

32. Ejike CECC, Collins SA, Balasuriya N, Swanson AK. Prospects of microalgae proteins in producing peptide-based functional foods for promoting cardiovascular health. Trends in Food Science and Technology. 2017; 59:30-36. Available from: https://doi.org/10.1016/j.tifs.2016.10.026

33. Semenov VA, Latkov NU, Koshelev YuA, Poznyakovskiy VM. Primenenye pantogematogena $\mathrm{v}$ sportivno-meditsinskoy praktike [Application of panthogematogen in sports medicine]. Tekhnika i tekhnologiia pishchevykh proizvodstv [Food Processing: Techniques and Technology]. 2014; 2:113-117.

34. Master PBZ, Macedo RCO. Effects of dietary supplementation in sport and exercise: a review of evidence on milk proteins and amino acids. Critical Reviews in Food Science and Nutrition. 2020; 60 Available from: https://doi.org/10.1080/10408398.2020.1756216

35. Poznyakovskiy VM, Gur'anov YuG, Bebenin VV. Pisheviye I biologicheski aktivniye dobavki: harakteristika, primeneniye, kontrol' [Food and biologically active additives: characteristics, application, control]. Kemerovo, Russia: Kuzbassvuzizdat; 2011. $275 \mathrm{p}$.

36. Technical Regulations of the Customs Union 027/2012 "On safety of special foodstuff including dietic clinical and dietic protective nutrition" adopted by the Council of the Eurasian Economic Commission Decision No 34 on June 15, 2012, and came into force on July $1,2013$.

37. Hofman DL, van Buul VJ, Brouns FJPH. Nutrition, Health, and Regulatory Aspects of Digestible Maltodextrins. Critical Reviews in Food Science and Nutrition. 2016; 56(12):2091-2100. Available from: http://dx.doi.org/10.1080/10408398.2014.940415

38. Latkov NYu, Poznyakovskiy DV, Avstrievskyh AN Experimentalnoe obosnovaniye I prakticheskaya realisatsia ratsionov pitanya dlya sportsmenov razlichnoy qualificacii [Experimental justification and practical realization of diet for sportsmen of various qualification]. Tekhnika i tekhnologiia pishchevykh proizvodstv [Food Processing: Techniques and Technology]. 2010; 3(18):77-81.

39. Khanferyan RA. Tonic (energy) drinks: the main components, efficiency and safety. Doctor. 2016; 10:72-75 (in Russian).

40. Winnick JJ, Davis JM, Welsh RS, Carmichael MD, Murphy EA, Blackmon JA. Carbohydrate Feedings during Team Sport Exercise Preserve Physical and CNS Function. Medicine and Science in Sports and Exercise. 2005; 37(2):306-315. Available from: https://doi.org/10.1249/01.MSS.0000152803.35130.A4 